\title{
Development of an antibiotic-free plasmid selection system based on glycine auxotrophy for recombinant protein overproduction in Escherichia coli
}

\author{
Luis Vidal*1, Josep López-Santín¹, Glòria Caminal² and Pau Ferrer ${ }^{1}$
}

\begin{abstract}
Address: ${ }^{1}$ Grup d'Enginyeria de Bioprocessos i Biocatàlisis Aplicada. Departament d'Enginyeria Química. Escola Tècnica Superior d'Enginyeria, Universitat Autònoma de Barcelona, 08193-Bellaterra, Spain and 2Unitat de Biocatàlisi Aplicada Associada al IIQAB (UAB-CSIC)

* Corresponding author
\end{abstract}

from The 4th Recombinant Protein Production Meeting: a comparative view on host physiology

Barcelona, Spain. 2I-23 September 2006

Published: 10 October 2006

Microbial Cell Factories 2006, 5(SuppI I):P85 doi:10.1 186/1475-2859-5-SI-P85

(C) 2006 Vidal et al; licensee BioMed Central Ltd.

\section{Background}

Antibiotics and antibiotics resistance genes have been traditionally used for the selection and maintenance of recombinant plasmids in hosts such as E. coli. Although a powerful selection tool, their use has been considered unacceptable in many areas of biotechnology by regulatory authorities. Indeed, there is much international scientific and regulatory focus on this issue [1]. For instance, the use of selection markers that confer resistance to antibiotics in vaccine plasmids may introduce the risk of transforming the patient's microflora and spread resistance genes. Moreover, in recombinant protein production for therapeutic use, the antibiotic must be eliminated from the final product. Another problem arises from the potential loss of selective pressure as a result of antibiotic degradation i.e. ampicillin can be degraded by $\beta$-lactamases in less than 30 minutes in high cell density cultures [2].

In this work, an alternative approach to prevent plasmid loss based on an amino acid auxotrophy complementation has been developed. A glycine-auxotrophic strain of E. coli M15 has been created using PCR products [3]. This strain contains an internal deletion of the glyA gene, which encodes for serine hydroxymethyl transferase (SHMT), an enzyme involved in the main glycine biosynthesis pathway in E. coli [4]. As a result, the glyA- strain can not synthesize glycine and, therefore, needs an external source of glycine or a genetic source of SHMT for growing on a defined medium. The construction of a plasmid selection system derived from the commercial vector pQE40 (QIAGEN) with glyA under the control of the constitutive weak promoter P3 [5], as well as its evaluation in batch and fed-batch cultures for expressing ramnulose 1phophate aldolase (RhuA) as a model for recombinant protein production has been evaluated.

\section{Results}

Disruption of the glyA gene in E. coli M15 was accomplished using a directed knockout gene method employing PCR products through homologous recombination [3]. The phenotype of the new strain M5 $\Delta$ glyA was tested on defined medium cultures with and without glycine, confirming the auxotrophy for glycine.

By using SOE-PCR [6], the glyA gene (referred here and after as $\beta$ fragment) from $E$. coli $\mathrm{K}-12$ was fused to the weak constitutive promoter P3 (referred here and after as $\alpha$ fragment). The fusion $\alpha \beta$ product was cloned into pQErham, a pQE40-derived vector for RhuA overexpression [7]. The resulting complementation vector, $\mathrm{pQE} \alpha$ Brham (figure 1), was used to transform the E. coli M15 $\Delta$ glyA host.

Erlenmeyers cultures with glycine-auxotrophic strain M15 $\Delta$ glyA transformed with the complementation expression plasmid can grow in defined medium adding neither glycine nor ampicillin. This indicated that the plasmid is 


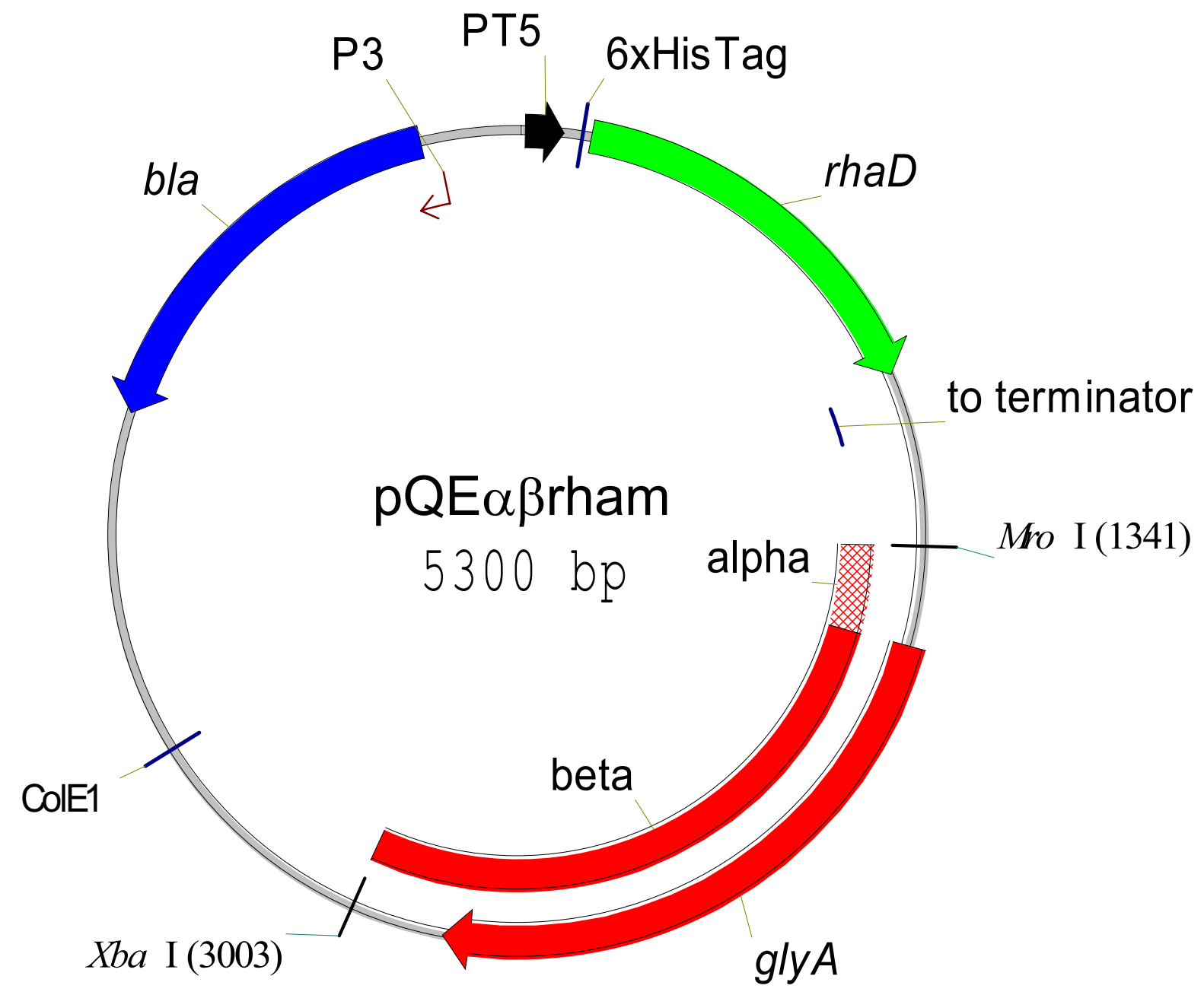

Figure I

Diagram of the complementation vector $\mathrm{pQE} \alpha \beta$ rham.

maintained and SHMT is being expressed, thereby generating an endogenous source of glycine. SDS-PAGE of soluble cytosolic proteins under non-inducing conditions indicated that SMHT was not being overexpressed.

The capacity of the new complementation system for producing the recombinant RhuA was compared to that of the conventional selection system based on antibiotic resistance (E. coli M15 pQErham). Induction with IPTG resulted in high overexpression of recombinant RhuA levels in E. coli M15 $\Delta$ glyA/pQE $\alpha \beta$ rham. However, such levels were slightly lower than those obtained in the conventional system. SDS-PAGE analyses of cell extracts revealed significantly higher expression levels (compared with non-inducing conditions) of a protein of about $45 \mathrm{kDa}$, corresponding to SHMT. This suggested that the down- stream orientation of $\alpha \beta$ fragment in relation to the strong T5 promoter could cause a read-through of RhuA gene in the presence of IPTG, i.e. resulting in higher SHMT expression levels. This phenomenon could exert a metabolic burden on the host cell, resulting in lower specific RhuA activity levels.

High cell density fed-batch cultures using the novel complementation system were performed using an exponential feeding profile strategy analogous to that previously developed for the conventional system [7]. In particular, a fed-batch cultivation with a controlled specific growth rate of $0.2 \mathrm{~h}^{-1}$ (final $\mathrm{DO}_{600 \mathrm{~nm}}=185$ ) was performed without ampicillin. Induction with IPTG allowed obtaining high RhuA production (28483 $\mathrm{U} \mathrm{l}^{-1}$ ) and productivity (1636 U l-1 $\mathrm{h}^{-1}$ ) levels. 


\section{Conclusion}

The new selection maker based on a glycine-auxotrophy strain plus a plasmid harboring the glyA gene under the $\mathrm{P} 3$ weak promoter is a promising tool, not only for recombinant protein production, but also for vaccine plasmids production processes where antibiotics can not be present in the medium formulation. Besides, the use of a chemically defined medium avoids the risk of employing components of animal origin that may contain viruses or prions [1], increasing the safety level of the system for industrial processes.

\section{Acknowledgements}

Authors wish to acknowledge Dr. Wanner for providing the knockout system. This work was support from MEC CTQ2005-0I706. PPQ. The

Department of Chemical Engineering is the Unit of Biochemical Engineering of the Centre de Referència en Biotecnologia de la Generalitat de Catalunya (CeRBa).

\section{References}

I. Glenting J, Wessels S: Ensuring safety of DNA vaccines. Microbial Cell Factories 2005, 4:26.

2. Jung G, Denefle P, Becquart J, Mayaux JF: High-cell density fermentation studies of recombinant Escherichia coli strains expressing human interleukin-I-beta. Ann Inst Pasteur-Microbiol 1988, 139:129-146.

3. Datsenko KA, Wanner BL: One-step inactivation of chromosomal genes in Escherichia coli K- 12 using PCR products. Proc Natl Acad Sci USA 2000, 97:6640-6645.

4. Stauffer LT, Plamann MD, Stauffer GV: Cloning and characterization of the glycine-cleavage enzyme-system of Escherichia coli. Gene 1986, 44:219-226.

5. Lartigue MF, Leflon-Guibout W, Poirel L, Nordmann P, Nicolas-Chanoine $\mathrm{MH}$ : Promoters $\mathbf{P 3}, \mathbf{P a} / \mathbf{P b}, \mathbf{P 4}$, and $\mathbf{P 5}$ upstream from $\mathrm{bla}(T E M)$ genes and their relationship to beta-lactam resistance. Antimicrob Agents Chemother 2002, 46:4035-4037.

6. Sambrook J, Maniatis T, Fritsch EF: Molecular cloning: A Laboratory manual. Cold Spring Harbor, NY 1989.

7. Vidal L, Ferrer P, Alvaro G, Benaiges MD, Caminal G: Influence of induction and operation mode on recombinant rhamnulose I-phosphate aldolase production by Escherichia coli using the T5 promoter. J Biotechnol 2005, I I 8:75-87.

Publish with Biomed Central and every scientist can read your work free of charge

"BioMed Central will be the most significant development for disseminating the results of biomedical research in our lifetime. "

Sir Paul Nurse, Cancer Research UK

Your research papers will be:

- available free of charge to the entire biomedical community

- peer reviewed and published immediately upon acceptance

- cited in PubMed and archived on PubMed Central

- yours - you keep the copyright

Submit your manuscript here:

http://www.biomedcentral.com/info/publishing_adv.asp 